\title{
LITERATURE REVIEW: GAMBARAN KARAKTERISTIK PRURITUS UREMIK PADA PASIEN GAGAL GINJAL KRONIK YANG MENJALANI HEMODIALISA
}

\author{
Rizal Mahardian', Hana Ariyani'2, Yuyun Solihatin ${ }^{2}$ \\ Universitas Muhammadiyah Tasikmalaya ${ }^{1,2,3}$ \\ mahardian189@gmail.com
}

\begin{abstract}
ABSTRAK
Penelitian ini dilatarbelakangi tingginya prevalansi pruritus pada pasien GGK yang menjalani hemodialisa. Tujuan dilakukannya penelitian ini untuk mengetahui gambaran karakteristik pruritus uremik pada pasien GGK yang menjalani hemodialisa berdasarkan telaah literatur review. Metode yang digunakan dalam penelitian ini adalah literature review dengan mengumpulkan beberapa artikel jurnal yang populasinya terdiri dari 169 artikel yang terdiri dari jurnal nasional dan internasional yang berkaitan dengan karakteristik pruritus pada pasien GGK yang menjalani hemodialisa. Sedangkan sampel dalam penelitian ini adalah 14 Jurnal yang terdiri dari 3 jurnal nasional dan 11 jurnal internasional. Teknik pengumpulan sampel pada penelitian yaitu dengan cara mengakses jurnal dari internet dengan search engine Google Scholar, Directory of Open Access Journals (DOAJ) dan PubMed. Teknik analisis data yaitu menggunakan Introduction, Methods, Result, Discussion (IMRD). Hasil penelitian melalui telaah literature menunjukan bahwa pruritus lebih sering pada usia di atas 55 tahun; lebih sering muncul pada jenis kelamin laki-laki; rata-rata pasien yang menderita pruritus yakni pendidikan menengah dan sering dirasakan pada pasien yang tidak bekerja dibandingkan dengan yang bekerja; skala pruritus rata-rata dirasakan pada skala sedang; pruritus sering muncul pada malam hari; rata-rata durasi pruritus terjadi kurang dari 6 jam perhari; area tubuh yang sering terkena pruritus yaitu dada, punggung dan bokong. Tetapi hal tersebut tidak menutup kemungkinan juga dapat muncul di seluruh tubuh serta berdampak mempengaruhi kualitas hidup terutama kualitas tidur. Saran bagi penelitian selanjutnya diharapkan dapat menjadi referensi untuk dilakukannya penelitian selanjutnya mengenai karakteristik pruritus pada pasien GGK yang menjalani hemodialisa khususnya pengaruh lama hemodialisa terhadap munculnya pruritus.
\end{abstract}

\section{Kata Kunci : Gagal Ginjal Kronik (GGK), hemodialysis, pruritus uremic}

\section{ABSTRACT}

This research motivated by the high prevalence of pruritus in Chronic Renal Failure $(C R F)$ patients undergoing hemodialysis. It can affect the patient's quality of life. The purpose of this research is to describe the characteristic of uremic pruritus characteristics in CRF patients who undergo hemodialysis based on review literature study. The method used in this study is literature review by collecting several journal 
articles whose population consists of 169 articles consisting of national and international articles relating to the characteristics of pruritus in CRF patients undergoing hemodialysis. The samples collection technique in this study are by accessing the articles from internet database: Google Scholar search engines, Directory of Open Access Journals (DOAJ) and PubMed. Data analysis techniques are using Introduction, Methods, Result, Discussion (IMRD). The results of the study show that pruritus more often at the age of over 55 years; More often appears on male gender; The average of patients suffering from pruritus is secondary education and is often felt in patients who do not work compared to those working; Average pruritus scale felt at medium scale; Pruritus often occurs at night; The average duration of pruritus occurs less than 6 hours per day; Areas of the body that are often exposed to pruritus are the chest, back and buttocks. But it does not close the possibilities can also appear throughout the body and affects the quality of life especially sleep quality. Advice for further research is expected to be the reference for further research on the charactheristic pruritus in CRF patient who undergo hemodyalisis, especially correlation between duration of hemodyalisis and the emergence of uremic pruritus..

Keywords: Chronic Renal Failure (CRF), hemodialysis, uremic pruritus

\section{PENDAHULUAN}

Gagal Ginjal Kronik (GGK) merupakan masalah penyakit di bidang nefrologi dengan angka kejadian yang cukup tinggi dengan etiologi yang luas dan komplek. Data World Health Organization (WHO) pada tahun 2015 mengemukakan bahwa angka kejadian GGK di seluruh dunia mencapai $10 \%$ dari populasi, sementara itu pasien GGK yang menjalanihemodialisa mencapai 1,5 juta orang di seluruh dunia (Anggeria \& Resmita, 2019). Berdasarkan Riset Kesehatan Dasar (Riskesdas, 2018) prevalensi GGK di Indonesia pada tahun 2018 terdapat $3,8 \%$. Hal ini menunjukkan terdapat kenaikan sebesar 1,8\% dibandingkan dengan tahun 2013 yaitu sebesar $2 \%$ (Msn, 2019).

Penyakit GGK merupakan gangguan fungsi tubuh yang menyebabkan penumpukkan sisa metabolisme dan cairan di dalam tubuh. (Authority, 2016). Menurut Vaidya dkk (2019) dalam (Ariyani, et al., 2019) GGK dapat dijadikan diagnosa apabila laju filtrasi glomerulus atau Glomerular Filtration Rate (GFR) kurang dari $60 \mathrm{ml} / \mathrm{menit} / 1,73 \mathrm{~m} 2$ selama 3 bulan atau lebih. GGK bersifat progresif dan irreversible. Seseorang yang sudah terdiagnosa GGK diharuskan melakukan tindakan medis salah satunya melakukan terapi hemodialisis atau dikenal dengan istilah cuci darah. Tujuan terapi hemodialisis yaitu mencegah kematian tetapi tidak dapat menyembuhkan atau memulihkan fungsi ginjal secara keseluruhan (Kurniawati \& Asikin, 2018).

Adanya penyakit penyerta setelah mengalami gangguan ginjal pada pasien GGK yang menjalani hemodialisa tidak dapat dihindari, dimana komplikasi tersebut dapat menimbulkan ketidaknyamanan. 
(Wiliyanarti \& Muhith, 2019). Pruritus merupakan bentuk ketidaknyamanan pasien GGK disebabkan oleh toksik uremik. (Asri \& Zuryati, 2018). Intensitas dan distribusi pruritus yang terjadi pada pasien akan meningkat secara signifikan dari waktu ke waktu. Tingkatan tersebut bervariasi mulai dari skala ringan sampai berat. Hal tersebut dipengaruhi oleh lamanya pasien mengalami gangguan ginjal. Intensitas dan distribusi pruritusakan lebih parah dialami oleh pasien yang menjalani terapi hemodialisa.

Melihat dari penyebab dan dampak yang disebabkan oleh pruritus, maka peneliti tertarik untuk untuk menelaah jurnal yang berhubungan dengan karakteristik pruritus pada pasien GGK yang menjalani hemodialisa.

\section{METODE PENELITIAN}

Penelitian ini adalah penelitian literature review. Tujuan dari metode ini adalah untuk membantu peneliti lebih memahami latar belakang dari penelitian yang menjadi subyek topik yang dicari serta memahami kenapa dan bagaimana hasil dari penelitian tersebut sehingga dapat menjadi acuan untuk penelitian baru. Penelitian ini menggunakan literature review, yang bertujuan untuk mengetahui gambaran karakteristik pruritus pada pasien Gagal Ginjal Kronik (GGK) yang menjalani hemodialisa. Adapun yang menjadi populasi di penelitian ini adalah 169 jurnal yang terdiri dari jurnalnasional dan jurnal internasional yang berkaitan dengan karakteristik pruritus pada pasien GGK yang menjalani hemodialisa. Sampel dalam penelitian ini adalah 14 jurnal yang terdiri dari 3 jurnal nasional dan 11 jurnal internasional yang berkaitan dengan karakteristik pruritus pada pasien GGK yang menjalani hemodialisa khusunya karakteristik pasien dan dampak pruritus pada kualitas hidup.

Teknik pengumpulan sampel pada penelitian ini dilakukan dengan cara mengakses jurnal dari internet dengan search engine google scholar, PubMed dan Directory of Open Access Journal (DOAJ) menggunakan kata kunci (keyword) sesuai dengan topik penelitian yaitu pruritus uremic, GGK dan hemodialysis. Untuk tahapan penelitian dilakukan melalui 5 tahapan yang terdiri dari: identifikasi masalah dalam tahap ini didapatkan 169 artikel jurnal yang terdiri google scholar sebanyak 137 artikel jurnal, PubMed sebanyak 20 artikel jurnal dan dari DOAJ sebanyak 12 artikel jurnal. Pada tahap screening diperoleh 75 judul penelitian yang terdiri dari 55 judul dari google scholae, 13 judul dari PubMed dan 7 judul dari DOAJ. Kemudian tahap selanjutnya dilakukan penilaian kualitas. Pada tahap ini jurnal artikel yang seleksi dan sesuai dengan kriteria yang sudah ditetapkan menjadi 14 jurnal artikel. Kemudian dilakukan analisa data dengan cara membaca seluruh isi artikel dengan jumlah 14 jurnal artikel kemudian di masukan dalam tabel analisa yang meliputi judul artikel, penulis artikel, desain penelitian, tujuan penelitian, hasil penelitian dan pembahasan. Pada tahap akhir 
kemudian dilakukan penulisan hasil analisa data yaitu melihat persamaan dan perbedaan pada setiap hasil artikel yang sudah dianalisa.

Tahap ini peneliti membaca seluruh isi artikel dengan jumlah 14 artikel, kemudian dimasukan dalam tabel analisa yang meliputi judul artikel, penulis, desain penelitian, tujuan penelitian dan hasil penelitian.

\section{HASIL PENELITIAN}

Berdasarkan hasil analisa data pada 14 artikel jurnal dari nasional maupun Internasional, terdapat gambaran pruritus pada pasien GGK yang menjalani hemodialisa terdiri dari karakteristik pasien GGK yang mengalami pruritus meliputi usia, jenis kelamin, pendidikandan status pekerjaan. Gambaran pruritus yang lainnya terdiri dari skala pruritus, durasi pruritus, waktu pruritus muncul dan area tubuh yang mengalami pruritus.

\section{PEMBAHASAN}

Pruritus merupakan keluhan dirasakan oleh pasien GGK yang merupakan rasa gatal yang dapat berdampak pada kualitas hidup pasien yang menjalani terapi hemodialisa. Pruritus merupakan sensasi yang tidak menyenangkan pada kulit, menyebabkan keinginan untuk menggaruk yang mengganggu dan tidak menyenangkan dan memiliki prevalensi tertinggi di antara manifestasi kulit pada penyakit ginjal. (Ersoy \& Akyar, 2019). Prevalensi kejadian pruritus pada pasien GGK yang menjalani hemodialisa terbilang cukup tinggi yaitu antara 25,2\% sampai dengan 64,5\%. (Weiss, Mettang, Tschulena, \& Weissha, 2015; Suseł, Batycka-Baran, Reich, \& Szepietowski, 2014; Adejumo, Akinbodewa, Alli, Olatunji, \& Ibukun, 2016; Rehman, Munib, Ramadas, Khan, \& Rayner, 2018; Min, et al., 2016; Ersoy \& Akyar, 2019; Satti, et al., 2019; Weisshaar, et al., 2015; Adhikari, Kayastha, \& Bhatta, 2018; Vrucinic, Jakovljevic, \& Preradovic, 2015). Pruritus memiliki banyak faktor penyebab antaralain laki-laki, kadar ureum yang tinggi, peningkatan kadar kalsium, fosfor, dan mikroglobulin- $\beta 2$. (Pardede, 2010). Pruritus juga dipengaruhi oleh lama terjadinya gangguan ginjal serta pruritus yang berat dapat meningkatkan angka kematian pada pasien yangmenjalani terapi hemodialisa.

Karakteristik pruritus yang terjadi pada pasien GGK yang menjalani hemodialisa sangat bervariasi. Dimulai dengan karakteristik demografi pasien yang mempunyai keluhan pruritus di antaranya usia, jenis kelamin, pendidikan, status pekerjaan. Selanjutnya karakteristik pruritus yang terjadi pada pasien tersebut di antaranya skala pruritus, durasi pruritus, waktu munculnya pruritus dan area tubuh yang mengalami pruritus. (Elman, Hynan, Gabriel, \& Mayo, 2010). Sistem kekebalan berpengaruh terhadap terjadinya pruritus. Dengan meningkatnya rasio sel Th1 dan Th2. Sel Th1 diyakini menyebabkan pruritus dengan mengaktifkan sitokin dan sel inflamasi, dan sel Th2 dengan 
memastikan sekresi sitokin antiinflamasi. (Ozen, Cinar, Askin, \& Mut, 2018).

Dari hasil telaah jurnal yang telah dianalisa rata rata-rata usia pasien yang mengalami pruritus terjadi pada usia 55 tahun ke atas. (Sembiring, Nasution, \& Ariani, 2020; Ozen, Cinar, Askin, \& Mut, 2018; Weisshaar, et al., 2015; Adhikari, Kayastha, \& Bhatta, 2018). Dalam penelitian Nadarajah, dkk (2018) pruritus lebih banyak terjadi pada jenis kelamin laki-laki dibandingkan pada perempuan. Hal tersebut sejalan dengan penelitian yang dilakukan oleh Sembiring, dkk (2020) yang menyebutkan bahwa prevalensi pruritus pada laki-laki sebanyak $61,2 \%$. Tetapi data tersebut berbanding terbalik dengan penelitian yang dilakukan oleh Ersoy \& Akyar (2019) menyebutkan bahwa pasien wanitamemiliki prevalensi gatal yang lebih tinggi daripada pasien pria, hal tersebut dikarenakan sebagian besar terdapat perbedaan hormon dan faktor psikologis contohnya depresi dan gangguan kecemasan. Dalam kategori pekerjaan, orang yang tidak mempunyai pekerjaan cenderung lebih lama merasakan pruritus dibandingkan dengan orang yang bekerja. (Satti,et al., 2019; Ersoy \& Akyar, 2019). Hal ini disebabkan karena orang pekerja membuat seseorang menjadi sibuk yang memberikan efek penyamaran pada psikologis yang mungkin dengan sendirinya menekan rasa gatal. (Satti, et al., 2019).

Kualitas prutitus pada setiap pasien bervariasi. Pruritus ada yang bersifat terusmenerus, luas dan sulit diatasi tapi pada beberapajuga yang bersifat sementara dan lokal. Namun, terapi hemodialisa kurang memberikan dampak terhadap pruritus pada GGK. Kebanyakan pasien menderita pruritus genaral di seluruh tubuh dengan frekuensi yang berbeda-beda. (Nadarajah, Astria, \& Yahya, 2018). Sebagian besar keluhan pruritus dirasakan pada skala sedang (Sembiring, Nasution, \& Ariani, 2020; Ersoy \& Akyar, 2019). Hasil ini sejalan dengan penelitian lainnya yaitu menyebutkan bahwa sebanyak $50,4 \%$ pasien mengeluhkan pruritus dengan skala sedang (Ozen, Cinar, Askin, \&Mut, 2018). Penelitian lain menyebutkan sebanyak 53,4\% reponden juga mengeluhkan pruritus dalam skala sedang. (Rehman, Munib, Ramadas, Khan, \& Rayner, 2018). Pada penelitian Ariyani \& Robby (2020) juga menyebutkan 34\% pasien mengeluh pruritus dengan skala sedang sampai berat. Durasi pruritus yang terjadi menurut hasil telaah jurnal menyebutkan bahwa rata rata pruritus terjadi kurang dari 6 jam per hari (Sembiring, Nasution, \& Ariani, 2020; Ersoy \& Akyar, 2019; Rehman, Munib, Ramadas, Khan, \& Rayner, 2018). Selanjutnya pruritus muncul biasanya pada pagi dan sore hari. (Min, et al., 2016). Tetapi pruritusjuga muncul pada malam hari (Daryaswanti I. P.,2019).

Pruritus muncul pada beberapa bagian tubuh bahkan bisa muncul di seluruh tubuh. (Rehman, Munib, Ramadas, Khan, \& Rayner, 2018). Data dari hasil penelitian yang dilakukan oleh Ozen, dkk (2018) 
menunjukkan ada $35,3 \%$ pasien mengeluh pruritus pada seluruh tubuh. Data ini sejalan dengan hasil penelitian Satti, dkk(2019) yang menunjukkan bahwa $40 \%$ pasien mengeluh pruritus dirasakan pada seluruh tubuh. Tetapi dari beberapa bagian tubuh yang paling dominan terkena pruritus yaitu pada area dada, punggung dan bokong. (Sembiring, Nasution, \& Ariani, 2020; Satti, et al., 2019; Adejumo, Akinbodewa, Alli, Olatunji, \& Ibukun, 2016; Ariyani \& Robby, 2020).

Dengan tingginya prevalensi pruritus pada pasien GGK yang menjalani hemodialisa berpengaruh pada kualitas hidup pasien. (Rahayu\& Sulistyaningsih, 2009). Pasien dengan pruritus mengalami kesulitan untuk mengatasinya. Pruritus adalah masalah yang semakin penting di antara pasien hemodialisa. Hal ini memberikan efek negatif pada kualitas hidup pasien, tidur, keadaan emosi, dan hubungan sosial. (Ozen, Cinar, Askin, \& Mut, 2018). Banyak penelitian yang menyebutkan bahwa pasien memiliki gangguan pada kualitas tidur. (Sembiring, Nasution, \& Ariani, 2020; Daryaswanti I. P., 2019; Ozen, Cinar, Askin, \& Mut, 2018). Tetapi pruritus tidak terlalu mempengaruhi aktivitas sehari-hari dari pasien. (Satti, et al., 2019).

Menurut peneliti karateristik pruritus sangat bervariasi. Hal ini disebabkan oleh latar belakang pasien yang beragam. Ada beberapa halyang menjadi penyebab terjadinya pruritus meskipun sudah dilakukan tindakan hemodialisa, selain akibat rusaknya ginjal yang sudah bersifat progresif.
Usia lansia menjadi salah satu faktor munculnya pruritus. Menurut peneliti, pada usia 41-60 tahun pasien mengalami berbagai masalah pada organ, seperti penurunan fungsi ginjal, maupun masalah kulit. Kulit akan menjadi kering(xerosis). Selain itu, pasien yang mengalami masalah gagal ginjal kronik, terjadinya atropi kelenjar sebasea, gangguan metabolism fosfor, kalsium, dan magnesium sehingga terjadinya uremia yang memperberat munculnya masalah pruritus. Selain itu jenis kelamin juga memiliki peran penting dalam munculnya pruritus. Laki - laki cenderung lebih banyak mengalami pruritus dibandingkan dengan perempuan. Tetapi hal ini belum ada data penyebab yang pasti kenapa lakilaki memiliki prevalensi pruritus lebih tinggi dibandingkan dengan perempuan sehingga diharapkan ada penelitian selanjutnya mengenai hal tersebut.

Mayoritas pasien hemodialisa memiliki pruritus dengan beberapa macam skala, durasi, area dan waktu yang berbeda. Skala yang paling dominan adalah skala sedang dengan durasi rata-rata kurang dari 6 jam dalam sehari. Menurut peneliti, hal ini disebabkan karena sebagian pasien masih belum mengetahui cara mengurangi rasa gatal dan mencegah infeksi akibat garukan, dengan menjaga kebersihan diri dan memotong kuku untuk mencegah garukan yang berakibat munculnya ekskoriasi, perdarahan maupun infeksi pada kulit. Dalam halini peran perawat sangat dibutuhkan untuk mengurangi skala pruritus dengan cara 
memodifikasi faktor resiko terjadinya pruritus dengan menganjurkan pasien untuk diet rendah fosfor, dimana akibat gangguan metabolisme fosfor dalam serum meningkat sehingga terjadi uremia yang menyebabkan munculnya pruritus.

Area yang sering mengalami pruritus adalah punggung dan bokong. Area punggung menjadi area yang paling umum terjadi karena punggung merupakan area yang yang paling luas dan sering mengalami penekanan. Jika hal ini tidak diatasi dengan tepat maka akan mengakibatkan terganggunya kualitas hidup pasien seperti gangguan tidur.

Peran perawat yang dapat dilakukan yaitudengan cara memberi edukasi kepada pasien dan menganjurkan pasien untuk mengganti pakaian saat berkeringat, mencuci baju dengan sabun bayi agar serat kain menjadi lembut dan menjaga kelembaban kulit. Perawat juga harus mampu untuk membangun perspektif positif sehingga dapat meningkatkan kualitas hidup pasien menjadi lebih baik.

\section{SIMPULAN}

Dalam literature review penelitian ini ditemukan ada beberapa gambaran karakteristik pruritus pada pasien GGK yang menjalani hemodialisa. Karakterisitik tersebut terdiri dari karakteristik pasien GGK dan karakteristik pruritus itu sendiri. Usia lanjut cenderung lebih tinggi terkena pruritus yaitu usia 55 tahun ke atas.Pruritus lebih sering muncul pada jenis kelamin laki-laki. Rata-rata pasien yang mempunyai keluhan pruritus yaitu dengan pendididkan menengah. Pruritus sering dirasakan pada pasien yang tidak bekerja dibandingkan dengan yang bekerja.

Karakteristik pruritus yang terjadi terdiri dari skala yang dominan pada skala sedang dengan durasi yang bervariasi dan dapat muncul di beberapa waktu. Rata-rata durasi pruritus terjadi kurang dari 6 jam per hari. Pruritus sering muncul pada malam hari sehingga hal tersebut dapat mengganggu pada kualitas tidur pasien. Area tubuh yang sering terkena pruritus yaitu dada, punggung dan bokong. Tetapi tidak menutup kemungkinan pruritus dapat muncul di seluruh tubuh. dampak pruritus dapat mempengaruhi kualitas hidup terutama menggangu pada kualitas tidur.

\section{SARAN}

\section{Bagi Peneliti}

Dengan hasil penelitian ini diharapkan menambah dan memperkaya akses database jurnal yang berkaitan dengan gambaran karakteristik pruritus pada pasien GGK yang menjalani hemodialisa.

2. Institusi Pendidikan

Dengan hasil penelitian ini diharapkan dapat meningkatkan akses mahasiswa terhadapdatabase jurnal internasional yang berbayar.

3. Bagi Profesi Keperawatan

Diharapkan perawat harus mengetahui karakteristik pruritus yang sering terjadi pada pasien GGK yang menjalani hemodialisa serta supaya dapat meningkatkan atau memodifikasi karakteristik dan melakukan intervensi dengan 
pendekatan yang tepat terhadap pasien dengan pruritus uremik.

4. Bagi Pelayanan Kesehatan

Hasil penelitian ini diharapkan dapat disosialialisasikan supaya bisa diterapkan oleh perawat untuk meningkatkan pelayanan kesehatan.

5. Bagi Penelitian Selanjutnya

Hasil penelitian ini diharapkan dapat menjadikan data dasar primer untuk dilakukan penelitian selanjutnya terkait dengan karakteristik pruritus pada pasien GGK yang menjalani hemodialisa khususnya pengaruh lama hemodialisa terhadap munculnya pruritus.

\section{DAFTAR PUSTAKA}

Adejumo, O., Akinbodewa, A., Alli, O., Olatunji, A., \& Ibukun, I. (2016). Prevalence, Pattern and Association of Pruritus with Quality of Life in Chronic Kidney Disease Patients Attending Kidney Care Centre, Ondo City, Southwest Nigeria. Ethiop J Health Sci, 26(6), 549554.doi:10.4314/ejhs.v26i6.7.

Adhikari, L., Kayastha, R., \& Bhatta, K. (2018). Prevalence of uremic pruritus in chronic kidney patients undergoing maintenance hemodialysis at Kathmandu Medical College Teaching Hospital. Journal of Kathmandu Medical College, 5(4), 124127.doi:https://doi.org/10.3126/j kmc.v5i4.18610.

Aditya, A., Udiyono, A., Saraswati, L. D., \& Setyawan, H. (2018). Screening Fungsi Ginjal Sebagai Perbaikan Outcome Pengobatan Pada Penderita DiabetesMellitus
Tipe II (Studi Di Wilayah Kerja Puskesmas Ngesrep). Jurnal Kesehatan Masyarakat (eJournal), 6(1), 191-199.

Aisara, S., Azmi, S., \& Yanni, M. (2018). Gambaran Klinis Penderita PenyakitGinjal Kronik yang Menjalani Hemodialisis di RSUP Dr. M. Djamil Padang. Jurnal Kesehatan Andalas, 7(1), 42-50.

Alisa, F., \& Wulandari, C. (2019). Faktor- Faktor yang Berhubungan dengan Kepatuhan Pasien Penyakit Ginjal Kronik (PGK) Yang Menjalani Hemodialisa Di Rsup Dr.M. Djamil Padang. Jurnal Kesehatan Mercusuar, 2(2), 58-71.

Anggeria, E., \& Resmita, M. (2019). Hubungan Dukungan Keluarga dengan KecemasanPasien Gagal Ginjal Kronik di Ruang Hemodialisa Rumah Sakit Royal Prima Medan. Jurnal Keperawatan Priority, 2(1), 10.

Arifin, Z. (2019). Dukungan Keluarga pada Pasien Gagal Ginjal Kronik yang Menjalani Hemodialisa

Di Wilayah Blimbing Malang. Doctoral dissertation University of Muhammadiyah Malang, 11. Ariyani, H., \& Robby, A. (2020). Pruritus Overview of Chronic Kidney Failure Patients Using Visual Analogue Scale Application In Hemodialysis Unit General Hospital dr. Soekardjo, Tasikmalaya City, West Java. Journal of Physics: Conference Series, $\quad 1477$, 1-5. 
doi:10.1088/1742-

6596/1477/6/062014.

Ariyani, H., Hilmawan, R. G., S, B. L., Nurdianti, R., Hidayat, R., \& Puspitasari,

P. (2019). Gambaran Karakteristik Pasien Gagal Ginjal Kronis di Unit Hemodialisa Rumah Sakit Umum dr. Soekardjo Kota Tasikmalaya. Jurnal Keperawatan \& Kebidanan, 3(2), 1-6.

Authority, H. (2016). Hospital Authority. Retrieved from SMAR PATIEN: https://www21.ha.org.hk/smartp atient/EM/MediaLibraries/EM/E MMedia/Chronic- Renal-FailureIndonesian.pdf?ext=.pdf (20 Januari 2020). B, R. G., \& Burns, T. (2005). Lecture Notes on Dermatologi. (M. A. Zakaria, Trans.)Jakarta: Erlangga.

Daryaswanti, I. P. (2019). Gambaran TingkatKelembaban Kulit pada Pasien Gagal Ginjal Kronik Di Ruang Hemodialisa Rsud Buleleng. Bali Health Published Journal, 1(1), 39-46.

DiGiulio, M., Jackson, D., \& Keogh, J. (2014). Keperawatan Medikal Bedah. (K. Aulawi, Ed., \& D. Prabantini, Trans.) Yogyakarta: Rapha Publishing.

Elman, S., Hynan, L., Gabriel, V., \& Mayo, M. (2010). The 5-D itch scale: a new measureof pruritus. NIH Public Access, 162(3), 587593.

Ersoy, N. A., \& Akyar, İ. (2019). Multidimensional pruritus assessment in hemodialysis patients. BMC Nephrology, 20(42), 1-7. doi:10.1186/s12882-019-1234-0 Federer, W. T. (1977). Experimental Design Theory And Application, Third Edition. New Delhi Bombay Calcuta: Oxford and IBH Publishing. Harlim, A., \& Yogyartono, P. (2012). Pruritus Uremik pada Penyakit Gagal Ginjal Kronik. Majalah Kedokteran FK UKI, 28(2), 100111.

Ibrahim, I., Suryani, I., \& Ismail, E. (2017). Hubungan Asupan Protein dengan Kadar Ureum dan Kreatinin pada Pasien Gagal Ginjal Kronik yang Sedang Menjalani Hemodialisa di Unit Hemodialisa RS PKU Muhammadiyah Yogyakarta. JurnalNutrisia, 19(1).

Kemenkes. (2017). Situasi Penyakit Ginjal Kronik. Jakarta.

Kurniawati, A., \& Asikin, A. (2018). Gambaran Tingkat Pengetahuan Penyakit Ginjal DanTerapi Diet Ginjal Dan Kualitas HidupPasien Hemodialisis Di Rumkital Dr. Ramelan Surabaya. Amerta Nutrition, 125-135.

M.Black, J., \& Hawks, J. H. (2014). Keperawatan Medikal Bedah. Singapore: Elsivier.

Menaldi, S. L., Bramono, K., \& Indriatmi, W. (2018). Ilmu Penyakit Kulit dan Kelamin. Jakarta: Fakultas Kedokteran Universitas Indonesia.

Min, J.-W., Kim, S.-H., Kim, Y. O., Jin, D. C., Ho Chul Song, E. J., Kim, Y.-L., . . . Kim,Y. K. (2016). Comparison of uremic 
pruritus between patients undergoing hemodialysis and peritoneal dialysis. Kidney Res Clin Pract, 35(2), 107-113. doi:10.1016/j.krcp.2016.02.002

Msn. (2019, Maret 13). Tempo.co. Retrieved from https://www.msn.com/idid/kesehatan/health/hari-ginjalsedunia- intip-dua-penyebabutama-penyakitginjal/arBBUI1BQ (23 Januari 2020).

Nadarajah, S., Astria, I., \& Yahya, Y. F. (2018). Hubungan Karakteristik Klinis Dan Keparahan Pruritus Uremik Pada Pasien Gagal Ginjal Kronik Yang Mendapat Hemodialisis. Majalah Kedokteran Sriwijaya(3), 140-145.

Notoatmodjo, S. (2012). Metode Penelitian Kesehatan. Jakarta: Rineka Cipta.

Nurani, V. M., \& Mariyanti, S. (2011). Gambaran Makna Hidup Pasien Gagal Ginjal Kronik yang Menjalani Hemodialisa. Jurnal Psikologi Volume, 11(1).

Nursalam. (2017). Metodologi Penelitian Ilmu Keperawatan: Pendekatan Praktis. Jakarta: Salemba Medika.

Ozen, N., Cinar, F. I., Askin, D., \& Mut, D. (2018). Uremic Pruritus and Associated Factors in Hemodialysis Patients: A MultiCenter Study. Kidney Res Clin Pract, 37(2), 138-

147.doi:10.23876/j.krcp.2018.37 .2 .138 .

Pardede, S. O. (2010). Pruritus Uremik. SariPediatri, 11(5), 348354.
Rahayu, T., \& Sulistyaningsih, D. R. (2009). Pruritus. Majalah Ilmiah, 51(115).

Rehman, I. U., Munib, S., Ramadas, A., Khan, T.M., \& Rayner, H. C. (2018). Prevalence of chronic kidney disease-associated pruritus, and association with sleep quality among hemodialysis patients in Pakistan. PLoS One, 13(11),e0207758.doi:10.1371/jo urnal.pone.0207758.

Santoso, B. R., E, Y.M., \& Asbullah. (2016). Hubungan Lama Hemodialisis dengan Penurunan Nafsu Makan pada PasienGagal Ginjal Kronik di Unit Hemodialisa RSUD Ulin Banjarmasin. Dinamika Kesehatan, 7(1).

Saran, R., Robinson, B., C.A, K., Bragg-Gresham, J., Chen, X., Gipson, D., . . dkk.(2020). US Renal Data System 2019 Annual Data Report: Epidemiology of Kidney Disease in the United States. American Of Journal Kidney Disease (AJKD), 75(1), A6-A7.

Satti, M. Z., Arshad, D., Javed, H., Shahroz, A., Tahir, Z., Ahmed, M. M., \& Kareem, A. (2019). Pruritus Uremik: Prevalensi dan Dampak pada Kualitas Hidup dan Gejala Depresi pada Pasien Hemodialisis. Cureus, 11(7), e5178. doi:10.7759 / cureus.5178.

Sembiring, F., Nasution, S. S., \& Ariani, Y. (2020). Gambaran Pruritus Uremik Pasien Gagal Ginjal Kronik di Unit 
Hemodialisa Rumah Sakit Umum Pusat Haji Adam Malik Medan. Jurnal Perawat Indonesia, 4(1), 1-7.

Sugiyono. (2016). Metode Penelitian Kombinasi (Mixed Methods). Bandung: Alfabeta.

Suseł, J., Batycka-Baran, A., Reich, A., \& Szepietowski, J. C. (2014). Uraemic Pruritus Markedly Affects the Quality of Life and Depressive Symptoms in Haemodialysis Patients With End-Stage Renal Disease. Acta Derm Venereol, 94(3), 276-281. doi:10.2340/00015555-1749.

Vrucinic, n. V., Jakovljevic, B., \& Preradovic, L. (2015). Pruritus in hemodialysis patients: Results from Fresenius dyalisis center, Banja Luka, Bosnia and Herzegovina. Nasza Dermatologia Online, 6(2), 252256. doi:10.7241/ourd.20153.70.

Wahyuni, A., Lawati, U. Z., \& Gusti, E. (2019). Korelasi Lama Menjalani Hemodialisa Dengan Pruritus Pada Pasien Hemodialisa. Jurnal Endurance, 4(1), 117-125.

Wahyuni, P., Miro, S., \& Kurniawan, E. (2018). Hubungan Lama Menjalani Hemodialisis dengan Kualitas Hidup Pasien Penyakit
Ginjal Kronik dengan Diabetes Melitus di RSUP Dr. M Djamil Padang. Jurnal Kesehatan Andalas, 7(4).

Weiss, M., Mettang, T., Tschulena, U., \& Weissha, E. (2015). Prevalence of Chronic Itch and Associated Factors in Haemodialysis. Acta Derm Venereol, 95, 816-821. doi:10.2340/00015555-2087.

Weisshaar, E., Weiss, M., PasslickDeetjen, J., Tschulena, U., Maleki, K., \& Mettang, T. (2015). Laboratory and dialysis characteristics in hemodialysis patients suffering from chronic itch - results from a representative cross-sectional study. BMC Nephrol, 16, 184. doi:10.1186/s12882-015-01773.

Wijaya, A. S., \& Putri, Y. M. (2013). KMB 1 Keperawatan Medikal Bedah (Keperawatan Dewasa). Yogyakarta: Nuha Medika.

Wiliyanarti, P. F., \& Muhith, A. (2019). Life Experience Of Chronic Kidney Diseases Undergoing Hemodialysis Therapy. NurseLine Journal, 4(1), 55. 